\title{
KÖNYVJELZÖ
}

\section{KUPA LÁSZLÓ (SZERK.): KISEBBSÉGI AUTONÓMIA-TÖREKVÉSEK KÖZÉP-EURÓPÁBAN - A MÚLTBAN ÉS A JELENBEN}

\author{
(PTE-Bookmaster Kft., Pécs, 2009, 221 o.)
}

\section{BAYERNÉ SIPOS MÓNIKA}

A Kupa László által szerkesztett tanulmánykötet a Pécsi Tudományegyetem és a Bookmaster Kft. közös kiadásában jelent meg 2009-ben. A mú a 2008. november 14-én és 15-én Pécsett megrendezett konferencia előadásai alapján készültt tanulmányokat tartalmazza.

A közép-európai országokban az autonómiáról való gondolkodás már a középkorban jelentkezett, jóval a nemzetállamok etnikai homogenizálási törekvései előtt létezett már vallásilag motivált kisebbségvédelem. Sajnálatos dolog, hogy a 20. század elején végbement határváltozások következtében több milliós kisebbség került a határokon túlra. Ennek következtében bizonyos fokú autonómia elérése ma is célként fogalmazódik meg a méltánytalanul kisebbségi létbe sodort népcsoportok részérỏl. Mára az autonómia új jelentést kapott, ủj megvilágításban szerepel a kérdés, így időszerủ napirendre tủzni ezeket a témákat.

A kötetben közreadott tanulmányok a témát különböző aspektusokból közelítik meg. A nyitó tanulmányok a nemzetközi jog megítélése alapján vizsgálták az autonómiát, majd az autonómia és regionalizmus múltját és jelenét tárgyalták nemzetközi szintéren.

Szalayné Sándor Erzsébet azt a következtetést vonta le, hogy a nemzetközi jog jelen állása szerint klasszikus értelemben vett autonómiához való jogról nem lehet beszélni. Véleménye szerint, amellyel jómagam is egyetértek, az Európai Unió keretei között az integráció eredményeként egy pluralista szervezet keretein belül az egyének és a csoportok relatív autonómiája valósulhat meg a jövőben.

Fábián Gyula írásában egy aktuális kérdéssel, a „Koszovó effektussal” foglalkozik. Rövid tényállás után bemutatja, hogy napjainkban milyen területeken mutatkozik meg a „Koszovó effektus”. Felhívja a figyelmet arra, hogy a jövöben a nemzetállamoknak rugalmasabban kell kezelniük az autonómiához és az önrendelkezéshez való jogot, hogy ne ismétlődjék meg Koszovó esete.

Gerhard Seewann tanulmányában a nemzetiségi kérdést mutatja be a párizsi béketárgyalások tükrében. Az első világháborút fordulatként értelmezi a többség és a kisebbség kapcsolataiban. Megállapítja, hogy a tárgyalások eredményeképpen létrejött egy sor kisebbségvédelmi szerződés, másrészt Közép-Európa összeomlása több nemzetállam megalakulásához vezetett. Alkotásában a szerző a lengyelekkel kötött ki- 
sebbségvédelmi szerzödést mintaként mutatja be, mely alapján született a többi 13 megegyezés.

Az elmúlt évtizedekben, az európai fejlődés különbözö korszakaiban eltérően határozták meg a régió fogalmát. Horváth Gyula szerint ma még bizonytalannak tủnik az állam és a régiók közötti hatalommegosztás jövöje. A kérdés örök, mennyire tud majd érvényesülni a regionális autonómia? Mivel a regionális önkormányzatok kiépülése ma még nem tủnik reálisnak, ezért úgy látjuk, hogy a regionális autonómiára is várni kell.

Az egyházi autonómia egy-egy részének bemutatását célul tủző tanulmányok alkotják a második témakört. Kolumbán Vilmos József és Buzogâny Dezsö ezen írása az egyház és autonómia viszonyával foglalkozik. Kiemelik, tényként kezelik, hogy már a középkor folyamán létezett vallásilag motivált kisebbségvédelem. Jóval a nemzetállamok újjáéledése, kialakulása elött felszínre törtek az első függetlenségi törekvések az egyházban. A reformátori egyház hitvallása szerint az egyház autonómiájának lényege a következőkben rejlik: „Az egyház nem függ semmiféle földi tényezőtől, és csak egyetlen személyt fogad el vezetője gyanánt, mégpedig azt, aki áron váltotta meg és tette a maga tulajdonává. ... gazdasági fejlődésre önmagában nem jelent hátrányt, sőt kifejezetten előnyös is lehet." (65. o.)

Egy-egy határon túli magyar kisebbség sajátos autonómia-törekvéseinek, elképzeléseinek feltárását, bemutatását elvégzỏ tanulmányok képezik a kötet terjedelmesebb részét.

Több tanulmány foglalkozik Vajdaság tartománnyal, az ott fellángoló autonómiatörekvésekkel. A szerzők szerint az időről-időre megjelenö függetlenségi mozgalmak attól függnek, hogy a háttérben a politikai erők kiknek az érdekeit támogatják.

Ózer Ágnes felvázolja a Vajdaság etnikai sokszínúségéből, gazdasági, társadalmi és politikai különbözőségeiből eredő autonómiára való jog eszméjét és a más nemzetekkel való együttélés szükségességét. Mindezen nézetek Újvidékre kiterjedỏ hatását elemzi történelmi áttekintésben.

Gábrity Molnár Irén, szabadkai egyetemi tanár három kérdést vizsgál a tanulmányában. A Vajdaság Autonóm Tartomány státusát, a Nemzeti Tanácsok státusát, valamint a magyar koalíciós pártok autonómia koncepcióját.

Fazekas Márta munkájában arra keresi a választ, hogy a 20. század végén lehetőség vagy ábránd a délvidéki és a felvidéki autonómia. Véleménye szerint Vajdaságban jobb a helyzet, mint Szlovákiában. A szerző úgy látja, hogy a régióban a kulturális autonómiával szemben, amely már megvalósult, jelenleg kevés az esélye a területi autonómiának.

Több szerző foglalkozik a Kárpát-medencei délszláv kisebbségek valamelyikével. A Macedóniában élő albán kisebbség autonómia-törekvéseiről Pap Norbert és Végh Andor számol be. A kötet egyik legérdekesebb tanulmánya egy olyan témát tár elénk, mely sokunk számára ismeretlen. Kókai Sándor és Tóth József ismertetik az 1918-ban kikiáltott Bánsági Köztársaság történetét, és azt boncolgatják, hogy 1920-ban reális volt-e a Bánság újraalakításának gondolata.

Fazekas Márta és Molnár Margit mutatja be részletesebben a szlovákiai magyarság elképzeléseit. Fazekas Márta véleménye szerint ahhoz, hogy a Felvidéken meg- 
valósuljon a kulturális autonómia, a magyaroknak kellene az események mozgatórugóivá válni. Molnár Margit az egységes nemzetpolitika szükségességéről ír, melynek szerves részét kell, hogy képezze a mindig napirenden lévő autonómia.

A Kárpátalján élő kisebbségek autonómia-törekvéseiről Gönczi Andrea és Hajdú Zoltán ad áttekintést. Gönczi Andrea az 1930-as években kibontakozó függetlenedési törekvéseket vette górcső alá, mind a magyarok, mind a ruszinok között. Leszögezi, hogy a régióban tevékenykedő politikai szervezetek célja az autonómia megszerzése mellett a helyi gazdaság talpra állítása és a kisebbségek számára nemzetközileg szavatolt jogok érvényesítése volt.

Hajdú Zoltán kicsit másként közelíti meg a témát. Az államterületi változások függvényében vizsgálja a területi autonómia létjogosultságát. A szerző arra a megállapításra jut, hogy a térségben mindig a külső folyamatok határozták, határozzák meg az autonómia-lehetőségeket, a belső mozgások másodlagosak maradtak.

A konferencián természetesen nem maradhattak el a magyarországi kisebbségek autonómia-kérdéseivel foglalkozó tanulmányok, melyek a negyedik aspektust képviselik.

Bindorffer Györgyi 1848-tól 1920-ig követte nyomon a hazánkban élő kisebbségek autonómia-törekvéseit. Fontos megállapítást közöl a szerző, amikor azt írja, hogy 1920. június 4-e után új korszak kezdődött a magyar nemzetiségpolitikában, mivel ezután a fö hangsúly nem a határokon belül élö kisebbségekre, hanem a határokon túl rekedt magyarságra irányult.

Külön rész ismerteti a magyarországi horvátok kulturális autonómia-törekvéseit. Barics Ernö nyelvész szemmel közelítette meg a témát, és átfogóan tárgyalja a hazai horvátság helyzetét. Megállapítotja, hogy Magyarországon létezik egy, a horvátság összlétszámához képest kisebb, föleg értelmiségi réteg, amely vállalja a horvátságát, azt, hogy a horvát etnikai és kulturális korpuszhoz tartozik, igyekszik anyanyelvén beszélni, magas szinten elsajátítani a horvát nyelvet. Véleménye szerint a magyarországi horvátok jövője nagymértékben attól függ, mennyire lesznek képesek érvényesíteni nemzetiségi jogaikat, milyen mértékben tudnak alkalmazkodni horvátként, nem asszimiláltként, az új viszonyokhoz.

Gerner Zsuzsanna a hazánkban éló németek önképét mutatja be az aktuális kisebbségpolitika tükrében. Jómagam is egyetértek a szerzővel, amikor arról beszél, hogy 1945 után megrendült a magyarországi németek identitástudata, mivel a németek negatív megítélése miatt nem akarták, vagy nem tudták vállalni az anyanemzethez való tartozást. A rendszerváltozás óta változás tapasztalható, hiszen megnőtt az érdeklödés a kisebbségi alapon történő szerveződések iránt. A szerző a kisebbségi önkormányzati választásokon keresztül próbálja elemezni a helyzetüket, egy empirikus kutatás alapjaira támaszkodva.

Englender Petra egy újkeletü jelenséget, a német kisebbségi önkormányzatok tevékenységeinek súlypontjait vizsgálja a feladatalapú finanszírozási rendszerek tükrében. A szerzỏ szerint az 1993-ban elfogadott kisebbségi törvény értelmében ma a kisebbségi önkormányzatokon keresztül valósul meg a kulturális autonómia. A probléma csak ott van, hogy a kisebbségi önkormányzatok másban látják saját 
szerepüket, mint amit az állami szervek nekik szánnak. Inkább civil módra müködnek, mintsem önkormányzatként.

A kiadvány szerkesztỏjének, Kupa Lászlónak is szerepel egy tanulmánya a kötetben, mely Bibó István gondolatait foglalja össze az önrendelkezéssel kapcsolatban. Kupa azzal indokolja témaválasztását, hogy Bibónak A nemzetközi államközösség bénultsága címü munkáját tanulmányozva a központi elemet képező önrendelkezési elv szemszögéböl a kisebbségi autonómia is megjelenik elóttünk. Bibó István szerint megteremthető a nemzetközi politikai döntőbíráskodás intézménye, amely alkalmas lenne az önrendelkezési elv megvalósulásával kapcsolatos viták rendezésére.

„Kisebbségi autonómia-törekvések Közép-Európában - a múltban és a jelenben” kötetcím véleményem szerint lényegre törő és pontos. Még átfogóbb képet kaphattunk volna a függetlenedési törekvésekröl, ha a kötet alapját képezö konferencián szó esett volna az Európában sikeresen múködő autonómia-modellekröl. Elsősorban itt Szlovéniára, Ausztriára gondolunk. Érdemes lett volna meghallgatni, hogy jelenleg milyen stádiumában van a székely autonómia törekvés, és hogy milyen elképzelések léteznek a csángók jövőjét illetően.

A logikusan szerkesztett, közérthetö és átfogó tanulmánykötet mind az autonómia-törekvések iránt érdeklődő szakemberek, kutatók, mind a laikusok számára hasznos olvasmány.

A konferenciakötetben megjelent tanulmányokat a szerzők által felhasznált irodalomjegyzék és angol nyelvü 'summary' követi. Több tanulmányban találkozhatunk különböző ábrákkal, táblázatokkal, térképekkel, de mindezek néhol az olvasó számára nehezen követhetőek a nem megfeleló méretezés miatt.

A könyv érdeme, hogy valamennyi tárgyalt tanulmánynál a szerzök minden esetben megosztják az olvasóval az általuk fontosnak tartott, megválaszolásra váró kérdéseket. Ezt követően közlik az alternatívákat, felvázolják az adott témákat, felsorakoztatják a legfontosabb elönyöket, problémákat, hátrányokat. A szerzők gondolatainak, tapasztalatainak ezen logika mentén történő tárgyalása alkalmas az autonómiamodellek megismerésére, a jelenlévő problémák feltárására. A megoldáskeresés, az elgondolkodtató javaslatok, program-elképzelések valódi tudományos gondolkodásra vallanak.

A könyv felépítésekor jó megoldást választott a szerkesztö. A nemzetközi jogi megközelítéstöl halad az egyházi autonómia felé, majd ezután következnek a kisebbségi modellek, elképzelések.

A könyv legföbb erénye, hogy összefoglalja a kisebbségi autonómia-törekvéseket a középkortól napjainkig, és a fejlemények naprakész leírását nyújtja az olvasók számára. 